\title{
The Price of Collaboration: How Authoritarian States Retain Control
}

Comparative Political Studies 2020, Vol. 53(I3) 209|-2II7 (C) The Author(s) 2020

(c) (i)

Article reuse guidelines: sagepub.com/journals-permissions DOI: $10.1177 / 00104 \mid 4020912277$

journals.sagepub.com/home/cps

@SAGE

\section{Barbara Maria Piotrowska'(iD)}

\begin{abstract}
How does access to foreign or independent media affect the operation of a state security apparatus? This article answers this question concentrating on two characteristics of the informant network of the East German Stasi: the number of informants and their "price." Exposure to West German TV (WGTV) had the potential to decrease the supply of informants and increase the demand for them, pushing up the value of the payments the informants received, but leaving their quantity theoretically ambiguous. I verify this reasoning using a rare original data set of Stasi informants. Results show that informants were given approximately 70 East German marks worth of rewards more per year in the areas that had access to WGTV, as compared with areas with no reception-ironically an amount roughly equivalent to the cost of an annual East German TV subscription. These findings demonstrate how an authoritarian state can counteract the potentially destabilizing effect of foreign media.
\end{abstract}

\section{Keywords}

nondemocratic regimes, covert repression, authoritarian survival, media in authoritarian regimes

'Oxford University, Oxford, UK

\section{Corresponding Author:}

Barbara Maria Piotrowska, Blavatnik School of Government, Oxford University, Radcliffe Observatory Quarter, Woodstock Road, Oxford OX2 6GG, UK.

Email: barbara.piotrowska@bsg.ox.ac.uk 


\section{Introduction}

How does access to foreign or independent media affect the operation of a state security apparatus? The literature on media in authoritarian regimes concentrates on the impact that media, state-sponsored or independent, have on citizens. Most studies find that the media can effectively change people's behavior (see, for example, Adena et al., 2015; Enikolopov et al., 2011, 2017; Garcia-Arenas, 2016; Miner, 2015; Peisakhin \& Rozenas, 2018). However, in the important case of West German TV's (WGTV) influence on protests in the German Democratic Republic (GDR; 1949-1990), the empirical link is far less well established (Crabtree et al., 2014; Grdešić, 2014; Kern, 2010). This fact, combined with the historical importance and reputation of the Stasi, the East German secret police, highlights a mechanism that the media literature has so far overlooked: If access to nonstate media is easily predictable, authoritarian secret police may attempt to counteract any destabilizing effect that such an information source might have. This paper shows that factors that affect citizen support for a regime, such as foreign media, simultaneously affect the repressive response of the state. As a result, a destabilizing factor does not always affect state control negatively. The study presents a framework to understand the simultaneous effects a destabilizing factor may have on society and the state.

I analyze the operation of a state security apparatus by concentrating on the Stasi informant network: the number of informants and the amount that they were paid, two equilibrium quantities determined by the interaction of the supply of informants and the demand for them. When WGTV releases information that puts the regime's performance into perspective, passive popular support decreases, and so does the willingness of existing informants to continue their service. In my model, this decreases informant supply. At the same time, the regime knows that WGTV has the potential to destabilize society and hence needs the informants to control citizens. This is theoretically equivalent to an increase in demand for informants. Together, these two shifts affect both the informant reservation wage and informant network density. In particular, the price paid to informants should unambiguously increase, and the number of informants should change in line with the relative strength of the two shifts and informant price elasticity.

I test the empirical implications of my theory using a rare original data set of Stasi informants that was collected over a period of two years. The data include information on rewards received by informants, allowing me to isolate the variation in price, as well as covariates. Moreover, an analytically attractive feature of WGTV is that its reception varied across East Germany in a plausibly exogeneous way, which facilitates inference about the 
relationship between exposure to the destabilizing force and the price offered to informants.

Results show that informants were given approximately 70 East German marks worth of rewards more per year in the areas that had access to WGTV, as compared with areas with no reception-ironically, this was roughly equivalent to the cost of an annual East German TV subscription. This result is robust to controlling for a variety of factors which may otherwise have increased rewards, such as informant occupation, peripheriality of hometown, or party membership. The effect of WGTV access on informant network density is theoretically ambiguous and statistically insignificant.

These results shed new light on the effect of media in authoritarian regimes and on covert repression. They highlight a gap in the existing literature on the effect of independent or foreign media on authoritarian state stability. Explicitly modeling the state response to destabilizing forces such as access to WGTV on East German protests in 1989 offers an explanation for why the link between the two is not unambiguous. It also explicitly demonstrates how secret police operation, and pay specifically, can change in response to threats to the regime.

\section{Literature Review}

The themes developed in this article speak directly to two, so far independent, streams of literature: research on the effects of media on political outcomes in authoritarian regimes, as well as work on authoritarian regimes and their secret police.

Foreign or independent media can affect citizens of authoritarian states through two main channels: provision of alternative information that presents the regime in a more negative light (e.g., Enikolopov et al., 2011; Mcfaul, 2005; Miner, 2015) and aiding coordination (e.g., Edmond, 2013; Enikolopov et al., 2017; Mcfaul, 2005; Strömberg, 2015). As these respectively increase grievances and improve the political opportunity structure, in theory, access to the independent or foreign media should unambiguously increase the likelihood of protests under authoritarianism (Gurr, 2010; Tarrow, 2011). Accordingly, plentiful historical and theoretical accounts praise the Western media as key agents of change in East Germany specifically (e.g., Gieseke, 2011; Kuran, 1991; Lohmann, 1994). However, quantitative evidence of the relationship in the East German context is mixed. While Grdešić (2014) finds that West German coverage of protests was associated with an increase in protest in the first phase of the revolution, Kern (2010) and Crabtree et al. (2014) find no evidence that access to WGTV incited unrest. 
One aspect that a significant part of the literature on the effects of foreign and independent media does not cover is the reaction of the autocratic regime. This article is particularly interested in the response of the state security apparatus.

To retain control, authoritarian regimes need to have detailed knowledge about the level of popular support and the identity of rivals. However, in autocracies, this information is scarce because of repression of the opposition and the lack of freedom of speech (Dimitrov \& Sassoon, 2014), and so the state needs to use alternative sources of intelligence. Censuses are one option for collecting information about the size of the population segments that are deemed hostile, such as certain ethnic groups (Sassoon, 2011). Similarly, public opinion can be monitored using opinion polling and the analysis of citizen complaint letters (Dimitrov, 2014a, 2014b). However, information obtained this way provides only an aggregate overview of public opinion, which can change quickly, given the feasibly falsified preferences and the mechanisms behind the revolutionary bandwagons (Kuran, 1991). To identify and observe the radical mobilization activities, as well as to learn about the identity of specific opposition activists, states thus need to rely on surveillance and informants provided by their security systems (Davenport, 2005; Greitens, 2016; Sullivan, 2015).

Research on secret police roughly follows two directions. The first one is more state centered, setting out to explain the administrative and institutional differences between state security organizations and how they link to the challenges facing an autocrat (Blaydes, 2018; Greitens, 2016; Hassan, 2017; Persak \& Kamiński, 2005; Thomson, 2018, 2019). Some compare the situation in different countries, for example, Greitens (2016) argues that elite threats to the regime will lead to more fragmented and socially exclusive coercive institutions, whereas mass threats will be associated with the opposite kind of structure (Greitens, 2016). Others look at the variation between districts within one state. Thomson (2019) argues that an administrative reform that increased the number of districts in Polish People's Republic (and hence the number of local state security offices) led to competition between the officers. This, in turn, resulted in a faster growth in the number of informants in district more affected by the reform. Hassan (2017) explains the difference in the ethnic background of state security apparatus officers. He shows that in Kenya the President's coethnic internal security apparatus officers were sent to the "ethnically unaligned" areas with low levels of support for the regime, arguing that this is where coercion had the largest relative impact on his reelection.

The second stream of literature this article speaks to concentrates on the relationship between authoritarian states and their citizens and the motivations that led people to collaborate (Dennis, 2003; Fitzpatrick \& Gellately, 1996; 
Gellately, 1988; Hall, 2009; Müller-Enbergs, 2001; Scharpf \& Gläßel, 2020). Gellately's (1988), Fitzpatrick and Gellately's (1996), and Hall's (2009) work sees denunciations (often driven by private interest or "settling old scores") to the Gestapo as paramount in creating a self-policing state. Hall (2009) argues that these authors are wrong in discounting the importance of paid informers. Finally, Scharpf and Gläßel (2020) explain the low quality of secret police agents in terms of the organizational structure of the Argentinian security apparatus. Stasi-specific research has produced its own vast literature (see, for example, Dennis, 2003; Müller-Enbergs, 2001, 2008a, 2008b). Dennis (2003) explores the whole range of motivations that drove people to collaborate: from political and ideological conviction to coercion and fear. However, the most in-depth source of information about the Stasi are the publications of the Stasi Records Agency (Bundesbeauftragte für die Stasi-Unterlagen [BStU]) and the affiliated researchers. The volumes compiled by Müller-Enbergs cover every detail of the organization and running of the Stasi, as well as offer information about informant motivation. They consider both for the official guidelines (Müller-Enbergs, 2001) and the perspective of the sampled informants (Hempel, 1967 cited in Müller-Enbergs, 2008a).

This article bridges the two strands of literature. It speaks to the first, statecentered, one by quantifying the reaction of the state to the exposure to a destabilizing factor and the resulting variation in payments received by informants. However, it also touches upon the relationship between the state and the citizens, in that it addresses the effects of a destabilizing factor on people's willingness to collaborate. However, it is also different in several ways. First, because the Stasi relied primarily on information provided by informants (Bundesbeauftragte für die Stasi-Unterlagen, 2019; Florath, 2015), denunciations are not covered in my analysis. Second, the article concentrates on retention, rather than recruitment of informants, pointing out that the reasons for which people are recruited are not necessarily the same ones as those for which people continue their collaboration. Finally, the article combines various sources of information available through the Bundesbeauftragte für die Stasi-Unterlagen and creates a novel data set with quantifiable and original measures of authoritarian state responses.

\section{East German Stasi}

Ministerium für Staatssicherheit (MfS) or the Ministry of State Security, commonly referred to as the Stasi, was founded on February 8, 1950, with an objective to search society for those who posed a threat to the state from the view of the GDR government (Bruce, 2010). Between the 1950s and 1970s, it became the chief tool used for state control: Its tasks ranged from the 
"behind-the-scenes guiding of society" to the infiltration of the state and the bureaucracy (Bruce, 2010).

A dense, inclusive network of unofficial collaborators was key to the operation of the Stasi (Greitens, 2016, p. 279). In 1989, there were 91,000 fulltime Stasi officers and 189,000 unofficial informants (Müller-Enbergs, 2008a) in a country of about 16 million inhabitants.

The enrollment of Stasi informants differed from recruitment by other secret police organizations such as the Gestapo or rebel recruitment in several ways.

First, the informants were sought out by Stasi officers. As opposed to the unofficial Gestapo sources, denunciations are assumed to have played a smaller role (and denouncers were not automatically enrolled as informants; Bundesbeauftragte für die Stasi-Unterlagen 2019; Florath, 2015). This makes the mechanism presented in this article different from Kalyvas' (2006) account of denunciations in the Greek Civil War.

Second, recruitment of informants rarely involved direct violence. The preferred mode of informant enrollment changed over time as revealed in an analysis of the five guidelines of work with unofficial informants issued by the Stasi authorities (the guideline of 1950; guideline 21 of 1952; and guidelines 1/58, 1/68, and 1/79; Müller-Enbergs, 2001). From 1952 onwards, and especially since 1958, Stasi directives mention the use of political conviction as the main desired reason for informants to agree to provide information (Müller-Enbergs, 2001).

While understanding Stasi informant recruitment is necessary to see how it differed from other similar state security organizations, it is important to point out that this article concentrates on informant operation and retention, rather than recruitment. Differences in organization exist also here. Notably, the Stasi unofficial informants, unlike the full-time officers or the Gestapo official informers (Hall, 2009), were not regularly paid for their job. They could, however, receive gifts, both monetary and in kind, as payments for the gute Zusammenarbeit (good collaboration). Moreover, maintaining continued collaboration was important for the Stasi, as the recruitment and training of a new informant was very time intensive leading to a high fixed cost of each new informant. Thus, in the face of a factor that could decrease informants' willingness to collaborate, the Stasi was likely to invest in sustaining the existing collaboration. Offering informants higher value gifts was seen as an effective inducement (e.g., Bundesbeauftragte für die Stasi-Unterlagen, MfS, BV Gera Reg Nr. VI/21/80, Bd. 2, Bl.8).

\section{East and West German Media}

After the division of Germany after the World War II into east and west, their segmented populations were subject to diverging news. The GDR program was 
censored and used for propaganda, whereas the Western media provided both better entertainment and a different perspective on the news (Grossmann, 2015). Radio channels such as the Rundfunk im amerikanischen Sektor (RIAS or Broadcasting Service in the American Sector) and Radio Free Europe were conceived to provide people living behind the Iron Curtain with information independent of state censorship. A similar role for the television was played by the official West German news, which aimed to "counteract the information deficit caused by the Sozialistische Einheitspartei Deutschlands (SED) [the Socialist Unity Party of Germany] and break their information monopoly" (Schmidt, 2010, p. 12). For many East Germans watching WGTV was a regular "evening escape" and has led the GDR programming to be described as a "mass media without the masses" (Grossmann, 2015).

In contrast to the other states behind the Iron Curtain, the GDR was quick to put emphasis on the development of television, as it was competing for signal frequencies with West Germany. The first TV sets became available for sale in November 1952 and regular programming began in December 1952. The technology was popular, with 300,000 TV sets registered in the GDR in 1958 and eventually present in more than $90 \%$ of households (Noam, 1991).

Some of the WGTV broadcast transmitters were placed close to the border with the GDR, which gave East Germans access to these programs. However, because of the distance from the border with the Federal Republic of Germany (FRG) as well as the shape of the terrain, not all citizens in the east were able to watch WGTV. In particular, signal strength in the areas in the north-east and the south-east was too weak to allow people living there to access the WGTV. The population of these areas constituted about $15 \%$ of the total and the two areas were dubbed Tal der Ahnungslosen ("Valley of the Clueless"). ${ }^{1}$

The geographic variation in signal is noted both in the Stasi reports and in population surveys. A 1965 Stasi report from the Sebnitz county talks about the conversations that officers conducted with a radio and television specialist to establish the possibility of Western media reception. The conclusion was that due to the presence of hills, the signal was too weak to be used (Bundesbeauftragte für die Stasi-Unterlagen, MfS, BV Dresden KD Sebnitz 4466 Bd.II pp. 92-102). Furthermore, survey data collected by the Zentralinstitut für Jugendforschung (Central Institute for Youth Research) show that in Dresden, the only district in their sample that did not have access to the WGTV, only $5 \%$ of respondents reported watching it daily, whereas in other districts, this proportion was 65\% (Kern \& Hainmueller, 2009).

\section{WGTV and the Stasi}

To clarify my argument, I frame the analysis of the determinants of state control as a simple model of a market for informants. ${ }^{2}$ 


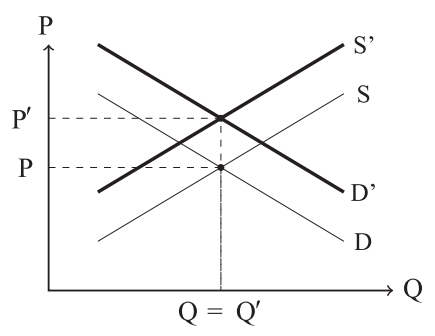

Figure I. Shifts in the demand and supply curves.

Exposure to a destabilizing factor causes an inward shift of the supply curve and an outward shift of the demand curve causing an increase in prices offered to the informants. The effect on quantity is ambiguous.

In the model, exposure of the population to WGTV has three effects on regime stability. First, it decreases the passive support of the population by broadcasting the foreign standard of life, as well as an outsider's perspective on the GDR politics. ${ }^{3}$ Second, in the case of unrest, broadcasting initial protests could lead to coordination of further protesters. Third, the information that puts the regime's performance into perspective, in addition to decreasing passive support, decreases the willingness of the existing informants to continue their service, increasing their reservation wage.

All these effects make protests more likely, by increasing citizen dissatisfaction, facilitating coordination, and making informants less likely to provide information about these two developments. In my theory, the Stasi's response was an increased demand for informants (Figure 1). As noted above, identifying and "educating" reliable sources was a time-consuming task; hence, it was a more cost-effective option to keep informants on for as long as possible, rather than enrolling new ones (Müller-Enbergs, 2001).

Archival materials support the theoretically derived mechanisms and demonstrate that in East Germany access to WGTV in fact influenced the behavior of both the society and the state.

First, archival Stasi reports reveal that the TV affected the population, as people could access news that presented the GDR in a more negative light than that offered by the official propaganda. Several documents link watching Western media to an increase in people overheard criticizing the regime (e.g., Bundesbeauftragte für die Stasi-Unterlagen, MfS, ZAIG 364, B1. 1-14 [7. Expl.]). The state was particularly concerned about the effect that Western media could have on the youth (Bundesbeauftragte für die Stasi-Unterlagen, MfS, ZAIG 397, Bl. 13-63 [5. Expl.]; Mork, 2011). However, even official state employees could be found guilty of watching the "ideologically corrupt" programs (Bundesbeauftragte für die Stasi-Unterlagen, MfS, ZAIG 
376, Bl. 1-11 [6. Expl.]). The Stasi reports also claim that watching WGTV increased the number of attempts at establishing postal contact with the West (Bundesbeauftragte für die Stasi-Unterlagen, MfS, ZAIG 1045, Bl. 1-7 [8. Expl.]). Before the Berlin Wall was erected, East German citizens had even visited the RIAS headquarters to illegally report about the daily life in the GDR (Kuschel, 2016). I argue that watching WGTV could similarly negatively affect the devotion of the existing informants.

Second, potential reception of WGTV mobilized state action. A report on the dangers posed by the WGTV went so far as to call the actions of the West German media "psychological warfare" (BV Leipzig AKG 2578). The report describes the media as exerting political and ideological influence both inside ("manipulation and undermining of the soul and thoughts in West Germany itself") and outside ("political-ideological weakening of the GDR"; BV Leipzig AKG 2578).

This threat mobilized state reaction. The most extreme case was the Aktion Enten and the resulting 1955 show trial of East Germans who had visited RIAS offices. They were consequently convicted of espionage and one was executed (Schlosser, 2015). A more general, but less violent, state-organized action was the Aktion Ochsenkopf, which took place in 1961. As a part of the initiative, the Freie Deutsche Jugend (Free German Youth) was identifying people with TV sets that had aerials which enabled reception of the WGTV and made them remove the aerials or did so themselves (Mork, 2011; Schlosser, 2015).

While the open hostility of the regime toward watching WGTV lessened over time, the catalog of the Stasi archives reveals that viewing WGTV was mentioned in reports as a proof of unreliability and the effect of the media was seen as problematic even in the late 1980s (see, for example, Bundesbeauftragte für die Stasi-Unterlagen, MfS, BV Dresden BdL 7675; Bundesbeauftragte für die Stasi-Unterlagen, MfS, BV Dresden KD DresdenStadt Nr.90833; Bundesbeauftragte für die Stasi-Unterlagen, MfS, BV Dresden Abt OT 358; Bundesbeauftragte für die Stasi-Unterlagen, MfS, BV Dresden Abt VIII 12173; Bundesbeauftragte für die Stasi-Unterlagen, MfS, BV Dresden Abt VIII/Fo/13565).

The Stasi not only identified the WGTV as a threat but also explicitly made it a focus point for their informants. A report on access to WGTV in the county of Sebnitz outlined the key issues to be clarified (Bundesbeauftragte für die Stasi-Unterlagen, MfS, BV Dresden KD Sebnitz 4466 p. 6):

- Where are the aerials [allowing the reception of WGTV] and where will new ones be built?

- Who sells and builds the aerials? 
- Can we identify the people who promote access to WGTV or organize communal viewings? (. . .)

All unofficial collaborators should be employed to observe and work on the identified persons. Moreover, all available connections should be used for the operation.

Hence, the archival materials render credibility also to the assumption of an increase in demand for informants by the state in the face of a destabilizing force.

Knowing that access to WGTV had a potential to affect both the supply of and the demand for informants of the Stasi, the theory yields two hypotheses.

Hypothesis 1: Informants in the areas with access to WGTV should be offered higher prices.

Both the decreased willingness of informants to provide information and the increased need of the Stasi to enroll sources in areas with WGTV reception exerted upward pressure on the informant "price." In the face of a fixed cost of enrolling new informants, the Stasi believed that gifts could increase the likelihood that an existing informant sustains his cooperation. An application of a leading officer of informant "Carlo" states that "the material tokens of appreciation for delivered services lead to a significant stimulation of IMS (informant) Carlo and to tightening of his relationship with MfS(. . .)," implying that the gifts were also used as an incentive for further collaboration (Bundesbeauftragte für die Stasi-Unterlagen, MfS, BV Gera Reg Nr. VI/21/80, Bd. 2, B1.8). Hence, I expect that the informants serving in areas with access to WGTV were offered gifts of a higher total value.

Hypothesis 2: The effect of access to WGTV on quantity of informants is theoretically ambiguous and has to be established empirically.

This is because the final effect on quantity depends on the relative sizes of the shifts and the elasticity of the two curves (Figure A3).

\section{Research Design}

To explore the empirical implications of my theory, I created a data set from a sample of 293 informants of the Stasi using files from the Federal Commissioner for the Records of the State Security Service of the former German Democratic Republic (Bundesbeauftragter für die Unterlagen des Staatssicherheitsdienstes der ehemaligen Deutschen Demokratischen Republik) also known as the Stasi 
Table I. Descriptive Statistics.

\begin{tabular}{lcc}
\hline Variable & Sample & Literature \\
\hline Women & $16.9 \%$ & $17 \%$ \\
Age & 30.8 at recruitment & $30 \%-40 \% 25-40$ \\
Service & Average 7 years & 6 to 10 years \\
Party membership & $43.3 \%$ & $40 \%-50 \%$ \\
\hline
\end{tabular}

Descriptive statistics of the sample are close to the averages quoted in the BStU publications (Müller-Enbergs, 2008a).

Records Agency or the Bundesbeauftragte für die Stasi-Unterlagen. ${ }^{4}$ Although the sample is of course small relative to the total stock of informants in operation throughout the history of the GDR, which is estimated at 624,000 (MüllerEnbergs, 2008b), it offers a remarkably wide geographic and temporal coverage. The selected informants come from 34 (of 217) counties and 11 (of 14) districts of the GDR. Their date of enrollment spans from 1950 to 1989, virtually the entire period of Stasi activity. Hence, the data allow a good overview of the general trends among the informants and avoid selection issues that would accompany limiting the sample to particular counties or a specific time frame. However, the thin coverage means that the data offer limited power to answer questions that require identification resting on temporal or geographic discontinuities. Moreover, as no new WGTV transmitters have been erected after 1958 and due to insufficient variation in access within districts, I cannot fruitfully utilize county or district fixed effects (Supplemental Table A1).

Given that the number of people without access to WGTV has been relatively low (ca.15\% of the population) and so random probability sampling would produce relatively few informants that did not have reception, I have used a nonproportional stratified sample, effectively oversampling the smaller group (Beamer, 2002; Lemm, 2010; Teddlie \& Yu, 2007). The resulting sample includes $61 \%$ of informants from areas with and 39\% from areas without access to the WGTV. ${ }^{5}$ Hence, in the following analysis, I weight my observations to restore the original proportions of population living in areas with and without WGTV reception.

To examine the quality of my sampling, I have compared the sample means of the most important variables with the means presented in the primary and secondary literature (Table 1; Müller-Enbergs, 2008a), demonstrating that my data look rather similar to the picture painted in the existing research.

\section{Effect of WGTV on Price}

The main prediction of the model is that the prices offered to informants should be higher in the areas with access to the WGTV. 
By prices I mean the average value of material or pecuniary rewards that an informant received for a year of their service denominated in the 1989 value of the East German mark (DDM). All payment receipts were kept in the informant files and were backed up by a note in the table of expenses. To construct the variable, all the payments were summed up and divided by the length of service of the informant.

The key explanatory variable is a binary variable accounting for access to WGTV. All the relevant TV transmitters were erected before 1958 and all but one were built before 1955. Hence, in the sample, there is no variation in access to WGTV within one area, making it impossible to harness such variation for identification. The two ways to conceptualize the access are using the "Valley of the Clueless" maps or applying the Longley-Rice algorithm, frequently used to estimate TV reception using information about signal frequency and transmitting antenna height. The regressions presented in the article define the regions with and without access to WGTV based on Longley-Rice radio signal propagation model and a cutoff level of $80 \mathrm{dBm}$ using data from Crabtree et al. (2014). While their specification uses a conservative $-86.5 \mathrm{dBm}$ cutoff, this article employs a less strict threshold as it resembles more closely the historical maps of the Valley and so is most likely to be related to where the Stasi thought the problem areas were (Witte, 1990). However, the results are robust to changing the cutoff level (Supplemental Table A2 [4]). ${ }^{6}$

The average annual value of the rewards in my reweighted sample is 75.5DDM, with $55 \%$ of the sampled informants getting rewards at any point of their service. However, a simple comparison of the means in the areas with and without access to WGTV reveals that the distribution of payments was far from homogeneous. The annual rewards offered to informants in the areas without WGTV reception were only ca. 28DDM, while if the population could view Western media, the payments rose to 83.6DDM per year. Moreover, in the former areas, only $40 \%$ of informants were paid at all, while in the latter, the proportion was $57 \%$.

Method and results. To evaluate the effect of the access to WGTV on the average annual payments to the informants, I use a simple ordinary least squares (OLS) estimator. The unit of observation and analysis in this data set is an informant and the preferred specification includes work occupation $(j)$ fixed effects:

$$
\left(\frac{D D M}{\text { year }}\right)_{i}=X_{i} \beta+c_{j}+u_{i},
$$

where $(D D M / \text { year })_{i}$ is the average amount of money that an informant $i$ got per year, $X_{i}$ is the vector of individual specific characteristics, and $c_{j}$ is the occupation $j$ fixed effects. 
Given the socialist setting, the salary of workers was determined by the "tariff" system, "established for all employees according to the same principles" (Adam, 1984, p. 80). Hence, workers in the same occupation, provided they were at the same grade, received very similar income. Including occupation fixed effects thus allows a comparison of the Stasi rewards given to people with the same jobs living in areas with and without access to the WGTV. ${ }^{7}$ This is particularly important as balance tests performed in Crabtree et al. (2014) show that the counties without access to WGTV differed slightly from counties with access in the share of skilled labor ( $61 \%$ vs $62 \%$, respectively) and the housing space $\left(26.15 \mathrm{~m}^{2}\right.$ vs $\left.27.34 \mathrm{~m}^{2}\right)$. Including fixed effects allows me to control for these inequalities and results in a comparison of people with potentially similar living conditions.

Another advantage of a socialist setting and central planning for identification is that the prices were announced centrally and, while there exists a debate about the exact effectiveness of population controls, people were not as free to move around as in democratic countries (Adam, 1984; Buckley, 1995; Cole \& Filatotchev, 1992; Gang \& Stuart, 1999). Hence, the usual caveats related to the cost of living and sorting do not apply.

Other controls used in the regression include the year of enrollment as an informant, gender, party (the Socialist Unity Party of Germany, Die Sozialistische Einheitspartei Deutschlands [SED]) membership, the number of organizations that the informant belonged to and whether she was enrolled for a specific task or for more general observation, education, and a coder dummy. The data were coded by two researchers, the author and a research assistant. Hence, a coder dummy is included to ensure intercoder reliability. Finally, if there was more to report on in the areas with access to WGTV, the higher annual value of rewards could be directly related to a higher productivity. To address this concern, I control for the number of pages of report filed. ${ }^{8}$

Table 2 presents the results of the preferred specification (1), as well as regressions accounting for other potentially important variables (2-5). First, instead of a dummy accounting for the access to WGTV, I use the expansion of access over time. Here, the key independent variable is weighted by the average number of TV sets per 100 households at the time of enrollment (2). ${ }^{9}$ Second, I add the number of pages of reports submitted by the informant to the regression to include a control for informant productivity (3). The two further specifications check the robustness of the results to clustering standard errors at the county level (which is appropriate, given that the measurements of access to WGTV are performed at the county level) (4), as well as to dropping the occupation fixed effects (5). 


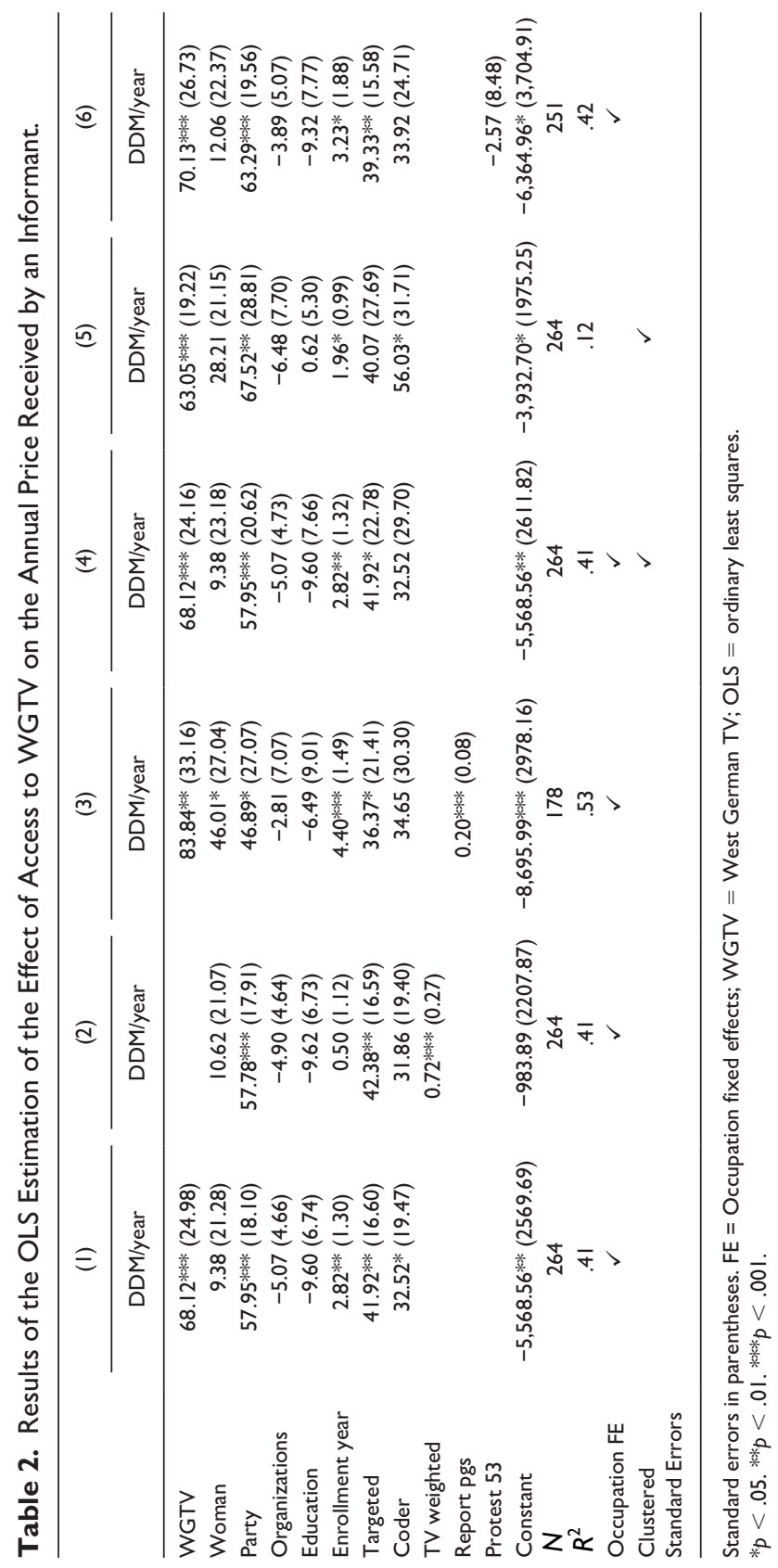


The final specification (6) controls for the number of protests in 1953 in the informant's county of origin. Other specifications and robustness checks can be found in the Supplemental Appendix (Table A2). They include using a dummy variable for payments (1), as well as subsetting the data only to those informants who were paid (2) and excluding the informants with the highest payments (3).

Regardless of specification, informants in areas with access to WGTV got around 70DDM more per year. For context, a basic monthly wage of a production worker was 770DDM, a monthly rent for a flat cost 58DDM, a pack of cigarettes cost 3.20DDM, and a monthly TV subscription payment cost 7DDM (Statistisches Jahrbuch der Deutschen Demokratischen Republik, 1965; Stephan \& Wiedemann, 1990). Hence, ironically, the annual additional value of gifts offered to informants in areas with access to WGTV was roughly equal to the price of an annual East German TV subscription. While not an amount comparable to a salary, it can be seen as sufficient to encourage further collaboration in the face of the reciprocity literature in psychology, which demonstrates that even small gifts can trigger reciprocal behavior, potentially disproportionately bigger than the value of the original gift (Cialdini \& Cialdini, 2007; Friedman \& Herskovitz, 1990; Katz et al., 2003). Another way to interpret this result is that an average informant ${ }^{10}$ living in an area with access to WGTV received gifts that were worth more than twice as much compared with those received by a comparable informant in the "Valley of the Clueless." Furthermore, given the link between the "material tokens of appreciation for delivered services" and informant activity identified in the case of IMS Carlo, such an increase in the value of gifts would have been seen by the Stasi as a significant "stimulation" for further collaboration (Bundesbeauftragte für die Stasi-Unterlagen, MfS, BV Gera Reg Nr. VI/21/80, Bd. 2, Bl.8)

Other factors that are positively correlated with the amount that the informants were offered per year are party membership and whether the informant was enrolled to provide specific information on particular people (Targeted) and informant productivity measured in the number of pages of reports they submitted. Members of the party were getting on average 59DDM more per year. Informants enrolled to provide more specific information were paid 40DDM more than if they only dealt with general surveillance. Finally, more report pages do produce a higher annual payment, as expected. However, all these effects are substantively weaker than that of access to WGTV.

Robustness checks. While the research has been designed to maximize its inference potential, there are three outstanding issues that need to be adequately addressed. First, the characteristics of places without access to WGTV 
could directly affect the amounts paid to informants. Second, given that some people were coerced to collaborate, one could ask whether different modes of enrollment affected how the informants were incentivized to continue their work for the Stasi. Third, Kern and Hainmueller (2009) show that having access to WGTV was not associated with a more negative perception of the regime in the late $1980 \mathrm{~s}$, potentially putting into question the supply shift.

First, while access to WGTV can be feasibly seen as exogenous, it is reasonable to ask questions about the relationship between the characteristics of the areas where the signal strength was weak and their possible direct relationship with the prices offered to the Stasi informants.

One way to address this concern is to consider variation within one, relatively small, region. While a full data set of Stasi finances has not been compiled yet, I was able to access the accounts of Neubrandenburg, one of the districts that experienced geographical variation in access to the WGTV. County expense totals for the account 6,000 are particularly interesting, as they covered sums paid specifically for grants to informants (Deutscher Bundestag, 1998, p. 44). While the data that I had access to cover only 2 years, 1988 and 1989, even in this small sample, the level of expenses depends on whether a county had access to WGTV. The coefficient is significant both statistically and substantively, with the difference in the amount paid per informant being 32.74DDM higher in areas with access to WGTV (Supplemental Table A4). This is particularly remarkable as the averaged aggregate amount is not too different from the individual-level data. Hence, the analysis of Neubrandenburg finances reveals that the differences in values of gifts were different even in counties within one district.

Another way to account for geographical heterogeneity is to introduce to the regression county-specific controls that could be correlated with both protest prevalence and access to WGTV, such as distances to key locations: Berlin and the Western border. Because of their distance from the capital, counties without access to WGTV could be more provincial and may have offered fewer opportunities to spend money. Moreover, higher distance from the Western border could be negatively correlated with dissatisfaction with the regime. Some of the reasons for this include lower probability of separation from their families, less frequent exposure to Western visits (Stegmann, 2018), and lower availability of escape routes to West Germany. All these could lead to lower prices being offered to the informants in the areas further east. To address these concerns, I introduce to the regressions variables accounting for the distance to Berlin and the distance to the Western border. Including either variable in the regression does not change the statistical significance of the key independent variable; however, it does decrease the size of the estimated coefficient (Supplemental Table A3). 
Hence, the results of differential payments depending on access to WGTV withstand aggregate level verification, as well as adding county-level controls.

Second, if some of the informants were coerced into collaboration, considering only the monetary incentives would not reveal the full extent of the Stasi's attempts to extract information. Fortunately, the informant files include a detailed description of the enrollment process. As political conviction was the preferred mode of enrollment since 1958, (Müller-Enbergs, 2001) the leading officers would try to convince the candidates of the necessity of their work to "fight the enemy" and mark in their reports the actual final method of enrollment, as well as any signs of nervousness or distrust. My data set includes a dummy variable that accounts for the enrollment process for each informant. An informant is coded as convinced if this is what the final report claims and there were no other mentions in the meeting reports that would point to the contrary. The "conviction" variable in my data set has a mean of $79 \%$, which is in line with the numbers quoted in the literature (Hempel, 1967).

I perform three pieces of analysis to control for varying incentives (Supplemental Table A5). First, I use a dummy variable for payments to check whether the informants who were enrolled on the basis of conviction were more or less likely to be rewarded (1). Second, I add the conviction variable to my baseline regression of the determinants of the amount paid to the informants, in general (2) and in particular in areas with access to Western TV (3). None of the regressions show a significant effect of the mode of enrollment on the value of rewards offered to informants during their service or whether they were paid at all, nor do they significantly affect the coefficient on access to WGTV.

Third, Kern and Hainmueller (2009) show that having access to WGTV was not associated with a more negative perception of the regime, which would disprove the reasoning behind the supply shift mechanism. However, this article insists on including the changes in supply of informants in the theory section for two reasons. First, the Kern and Heinmueller paper uses survey data from late 1980s. I argue that the effects of access to WGTV on supply and demand changed over time. Certainly the response of the regime toward watching Western media has evolved. The majority of the actions of the regime explicitly directed toward the WGTV audience took place in the 1950s and 1960s. Since the 1970s, the state response was less easily observable. In a 1973 speech, Erich Honecker, the General Secretary of the SED who led East Germany since 1971, proclaimed that "[in the GDR] everyone can switch the West German radio and TV on and off as they please" (Kuschel, 2016, p. 207). The ambiguity surrounding the legal status of watching WGTV 
remained in place until the fall of the regime. Hence, since the mid-1970s, the state seemed to perceive the media as less of a threat. Second, even if, in line with Kern and Heinmueller's findings, in the areas with access to the WGTV the supply of informants did not shift or even increased, empirically the effect of access to WGTV on price is still positive. This means that even if the shift in supply were opposite to the one postulated, the increase in demand was sufficiently strong to outweigh it.

\section{Effect of WGTV on the Density of Informant Network}

As discussed in the theory section, the second hypothesis postulates that the effect of access to WGTV on the density of informant network is theoretically ambiguous and hence an empirical question. Unfortunately, the main source of information on this topic, data on the number of informants per county per year compiled by Müller-Enbergs (2008b) suffer from gaps in both geographical and temporal coverage that renders them insufficient for rigorous estimation of the question at hand. These data were collected from statistics submitted to and then edited by Central Analysis and Information Group of the MfS, and although it was successively improved, it remains largely incomplete.

Performing an analysis of the relationship between access to WGTV and the number of informants per 10,000 citizens does not reveal any statistically significant effects (Supplemental Table A6). A lack of empirically discernible effect of access to WGTV on informant density network could be interpreted to mean that the shift in demand could have exactly matched the supply shift, highlighting the importance of the theoretical ambiguity. The literature on the effect of media usually concentrates on its effect on the population, which in the Stasi case only concerns the supply side of the relationship, making the informants less likely to collaborate. If this were the case, we should see a decrease in informant network density. However, the state reaction (demand shift) is as important for the final effect to be understood.

Nonetheless, given the above mentioned limitations of the data, these results need to be interpreted with caution. Although the data do contain information for some counties in every year, information for the 1950s and the early 1960 s is largely missing. The information is the most comprehensive between 1987 and 1989 when it covers more than a half of the counties. Unfortunately, restricting the observations to those years does not reveal a statistically significant relationship between the access to WGTV and density of the informant network either. Hence, a more rigorous discussion of the relationship remains an interesting question for future research following the publication of a more complete set of statistics on informant network. 


\section{Discussion}

The above theory and findings can be used to extract further lessons about the effects that destabilizing forces, such as access to foreign media, can have on authoritarian regime stability. First, it argues that state security response to independent media can weaken the destabilizing effect of exposure. Second, the theory can be generalized to explain differences in state response using relative sizes of shifts in supply and demand and price elasticities. Finally, the results presented here can help us understand the future of countries whose settings mirror the East German case, such as North Korea.

The main lesson of the article is how the East German regime has reacted to the exposure of its population and informants to the WGTV. This might offer an additional explanation for why there is no clear relationship between TV reception and protests in 1989. As the regime knew where the affected areas were, it intensified its efforts to prevent unrest by paying its informants more to sustain their collaboration. Hence, the apparent lack of influence of WGTV can be understood in terms of a sufficiently strong regime response that allowed it to sustain the collaboration from its informants and hence to maintain control.

Furthermore, the findings demonstrate that to analyze state and citizen action, it is important to choose the correct observable measure. If the analyzed variable were only the density of the informant network, a lack of discernible effect of WGTV on the number of informants could be interpreted as evidence for a lack of importance of WGTV for decisions made by the Stasi. However, when the price is also analyzed, it becomes clear that the way that the Stasi could counter the destabilizing effect of the WGTV was by offering informants higher rewards and thus additionally incentivizing them to provide information.

Second, the model can be generalized to provide new explanations for a range of government responses to threatening factors. Relative sizes of shifts in supply and demand and the elasticities of the curves can explain seemingly counterintuitive changes in observable indicators of government control. What factors can affect the shift sizes and the elasticities? A shift in demand can be smaller than that of supply if the regime does not have enough time to mobilize sufficient resources to counteract it. Elasticities of the curves can also be understood as the responsiveness of the population to incentives, which can be affected by indoctrination. Informants who are subject to state propaganda may be more likely to provide information for the same level of payment than those who do not believe the regime propaganda. On the demand side, if the number of informants is planned centrally, the response to price may be inelastic and the demand curve steep. Finally, if the state faces 
a budget constraint or imposes a price ceiling on the amount that can be paid to informants, then the quantity observed may be smaller. These and other factors can affect the final effect of a destabilizing force on state control.

Finally, the article provides insight into the possible effectiveness of nonregime media in settings that mirror the East German situation, such as North Korea. Just as in the German case, Korea has been divided into two countries, one of which enjoys significant levels of democracy, the other remaining one of the world's most oppressive dictatorships (Freedom House, 2015). Moreover, also in North Korea, there is demand for South Korean media, met with considerable numbers of illegal exports of DVDs from the South, as well as a significant number of radio listeners and TV audience attempting to access the southern programs (Kretchun \& Kim, 2012). Access to foreign media is also stronger in areas close to the border (Kretchun \& Kim, 2012). Finally, the democratic state airs news that is targeted specifically at the citizens of the nondemocratic regime. Moreover, as in East Germany, the regime has created an omnipresent system of surveillance, with a neighborhood watch program called the In-min-ban system that every North Korean citizen is required to belong to (Gause, 2012). According to my model, whether the media will ultimately destabilize North Korea will depend on whether the mobilizing effect they have on the citizens and the discouraging effect they have on the informants can outweigh the regime's power and expectations. The last decades have seen significant changes in the impact of foreign media in North Korea. The growth of illegal market activity over the last 20 years, as well as changes in technology allowing transmission of foreign media such as easy-to-smuggle USB sticks, has increased the proportion of the state population that can access foreign news and movies (Baek, 2016). Furthermore, defector surveys show that exposure to the nonregime media is associated with a more positive perception of the outside world (Kretchun \& Kim, 2012). Finally, there exists evidence that in recent years, North Koreans have become less likely to report on each other (Kang, 2014; Kretchun \& Kim, 2012). All these anecdotal pieces of evidence suggest that the outside media may have a destabilizing effect that the regime is not fully able to contain, especially given the high market demand for foreign movies and information (Baek, 2016). However, it is yet to become clear how these and other factors will play out on the Korean peninsula, as data on the state side of the equation remain scarce.

\section{Conclusion}

A destabilizing factor, such as access to foreign or independent media, does not always affect the level of state control negatively because it simultaneously affects two opposing sides of state stability-society and 
the regime. Society is affected in two ways: The passive support of ordinary citizens decreases (alongside increased opportunities for protest coordination)and the willingness of state security informants to collaborate wanes. At the same time, a regime willing to counteract the potentially destabilizing effect can invest in retaining the existing informants both because it needs them more, but also because they are less likely to provide information.

I analyze the effect WGTV had in East Germany to demonstrate how the above mechanism played out in the operation of the Stasi. As argued in the theory section, the regime did react to WGTV access by increasing its efforts to maintain its key source of control and covert repression - the network of informants. In areas with access to WGTV, the informants were paid about 70DDM more per year of service than in areas where the signal of Western media was too weak to allow reception. Given the conclusions of the literature on reciprocity and the beliefs of the Stasi, this amount would be sufficient to sustain collaboration.

This article offers important lessons for the study of covert repression and the impact of foreign or independent media. First, it highlights surveillance as a direct way through which citizens actively contribute to the stability of an authoritarian regime. Consequently, when analyzing the effect of variables that could affect the passive support for the regime, it is important to consider that some of these variables affect the effectiveness of the repressive apparatus at the same time. Second, the article provides a useful insight into authoritarian regimes' management of covert repression by demonstrating their reaction to a potential threat. This contributes an alternative explanation for the lack of clear-cut empirical evidence for the relationship between access to the WGTV and protest in East Germany. The model also offers a framework for understanding the circumstances that render state response sufficient, allowing to discriminate between factors that may be more or less successful in destabilizing authoritarian regimes. This is particularly important, given the hope often pinned on the impact of independent media on bringing down authoritarian states.

\section{Author's Note}

Earlier versions of this article have benefited from the feedback from participants of the Annual Meeting of the European Political Science Association 2016, the Annual Meeting of the Economic History Association 2016 Poster Session, University of Rochester Comparative Politics Workshop, and the Comparative Politics Dissertation Group, University of Oxford Politics Seminar, and Virtual Workshop on Authoritarian Regimes. 


\section{Acknowledgments}

I am grateful to G. Bingham Powell, Jr., Jakob Schneebacher, Roosmarijn de Geus, Jane Green, Gretchen Helmke, Maia King, Bethany Lacina, Cathrin Mohr, Randall Stone, and three anonymous reviewers for their comments and suggestions. I want to thank Ute Lipske at the Stasi Records Agency (Bundesbeauftragter für die Unterlagen des Staatssicherheitsdienstes der ehemaligen Deutschen Demokratischen Republik/ Bundesbeauftragte für die Stasi-Unterlagen [BStU]) for her help with the archival materials and Evgenija Kröker for her excellent research assistance.

\section{Declaration of Conflicting Interests}

The author declared no potential conflicts of interest with respect to the research, authorship, and/or publication of this article.

\section{Funding}

The author disclosed receipt of the following financial support for the research, authorship, and/or publication of this article: The author gratefully acknowledges financial support from the University of Rochester's Summer Seed Grant for International Field Research that was used to collect the Stasi data.

\section{ORCID iD}

Barbara Maria Piotrowska iD https://orcid.org/0000-0002-7625-2314

\section{Supplemental Material}

Supplemental material for this article is available online at the CPS website http:// journals.sagepub.com/doi/suppl/10.1177/0010414020912277

\section{Notes}

1. The exact interpretation of which areas comprised the valley varies. Sometimes, the term is used to refer only to the Dresden Basin, and other interpretations use it when talking about the south-east, as well as the north-east of the GDR. In this article, I use it to mean the areas both in the north-east and in the south-east of East Germany.

2. It can be argued that the situation of informant operation does not mirror the assumptions of competitive market. Rather, it is more similar to a perfectly discriminating monopsony where the only employer can offer each of the workers a wage equal to their reservation wage. However, the predictions and the logic of the analysis are very similar to that of a competitive market, and hence, the simple supply and demand analogy is sufficient to reflect the main theoretical mechanisms. A more detailed discussion of the perfectly discriminating monopsonist can be found in the Supplemental Appendix (section A2).

3. It is important to note here that some authors have argued that WGTV did not have a negative impact on the support for East German regime (Kern \& Hainmueller, 2009). I address this issue at length in the robustness tests. 
4. I have chosen to use the Inoffizieller Mitarbeiter zur politisch-operativen Durchdringung und Sicherung des Verantwortungsbereiches (IMS) type of informant, the societal coworkers for security in a particular area (IMS). They were by far the most common type (ca. 54\% of all informants), low-level informants, generally not assigned to a monitoring operation, but rather involved in blanket surveillance of the population (Müller-Enbergs, 2008a). Given their number, they were the informants most present in the East German society.

5. More information about the sampling method can be found in Supplemental Appendix section A1.

6. A detailed coding list of the sampled counties is provided in Supplemental Table A1 in attachments.

7. There are 41 different jobs in the sample, with more than 10 sampled individuals working as craftsmen, supervisors, locksmiths, engineers, clerks, drivers, doctors, and mechanics.

8. Not all the files contained folders with information about the meetings. However, I cannot be sure that the process by which this information is missing is random; hence, I am not adding this variable to the preferred specification.

9. The variable was constructed using data on the number of TV sets per 100 households at various points in time between 1955 and 1989 (Statista, 2019). Informant living in an area with access to WGTV would be assigned the number of TV sets per 100 households in the year in which he was enrolled. Otherwise, he would be coded as 0 .

10. A male party member with basic education enrolled for general observation in 1974 .

\section{References}

Adam, J. (1984). Employment and wage policies in Poland, Czechoslovakia and Hungary since 1950. Springer.

Adena, M., Enikolopov, R., Petrova, M., Santarosa, V., \& Zhuravskaya, E. (2015). Radio and the rise of the Nazis in prewar Germany. The Quarterly Journal of Economics, 130(4), 1885-1939.

Baek, J. (2016). North Korea's hidden revolution: How the information underground is transforming a closed society. Yale University Press.

Beamer, G. (2002). Elite interviews and state politics research. State Politics \& Policy Quarterly, 2(1), 86-96.

Blaydes, L. (2018). State of repression: Iraq under Saddam Hussein. Princeton University Press.

Bruce, G. (2010). The firm: The inside story of the Stasi. Oxford University Press.

Buckley, C. (1995). The myth of managed migration: Migration control and market in the Soviet period. Slavic Review, 54(4), 896-916.

Bundesbeauftragte für die Stasi-Unterlagen [Stasi Records Agency]. (2019). Forschungsschwerpunkte [Research Priorities]. https://www.bstu.de/informationenzur-stasi/forschung/forschungsschwerpunkte/\#c14824

Cialdini, R. B., \& Cialdini, R. B. (2007). Influence: The psychology of persuasion. HarperCollins. 
Cole, J. P., \& Filatotchev, I. V. (1992). Some observations on migration within and from the former USSR in the 1990s. Post-Soviet Geography, 33(7), 432-453.

Crabtree, C., Darmofal, D., \& Kern, H. L. (2014). A spatial analysis of the impact of West German television on protest mobilization during the East German revolution. Journal of Peace Research, 52(3), 269-284.

Davenport, C. (2005). Understanding covert repressive action: The case of the US government against the Republic of New Africa. Journal of Conflict Resolution, 49(1), 120-140.

Dennis, M. (2003). The Stasi: Myth and reality. Routledge.

Deutscher Bundestag [German Federal Parliament]. (1998). Bericht des Ausschusses für Wahlprüfung, Immunität und Geschäftsordnung (1. Ausschuß) zu dem Überprüfungsverfahren des Abgeordneten Dr. Gregor Gysi gemäß $\S 44$ b Abs. 2 Abgeordnetengesetz (Überprüfung auf eine Tätigkeit oder eine politische Verantwortung für das Ministerium für Staatssicherheit/Amt für Nationale Sicherheit der ehemaligen Deutschen Demokratischen Republik) [Report of the Committee on Election Examination, Immunity and Rules of Procedure (1st Committee) on the review procedure of Dr. Gregor Gysi in accordance with Section 44b (2) of the Members of the Bundestag Act (Review of activity or political responsibility regarding the Ministry for State Security / Office for National Security of the former German Democratic Republic)]. https://dip21.bundestag.de/dip21/btd/13/108/1310893.pdf

Dimitrov, M. K. (2014a). Tracking public opinion under authoritarianism. Russian History, 41(3), 329-353.

Dimitrov, M. K. (2014b). What the party wanted to know: Citizen complaints as a "barometer of public opinion" in communist Bulgaria. East European Politics and Societies, 28(2), 271-295.

Dimitrov, M. K., \& Sassoon, J. (2014). State security, information, and repression: A comparison of communist Bulgaria and Ba'thist Iraq. Journal of Cold War Studies, 16(2), 3-31.

Edmond, C. (2013). Information manipulation, coordination, and regime change. The Review of Economic Studies, 80, 1422-1458.

Enikolopov, R., Makarin, A., \& Petrova, M. (2017). Social media and protest participation: Evidence from Russia. https://ssrn.com/abstract=2696236

Enikolopov, R., Petrova, M., \& Zhuravskaya, E. (2011). Media and political persuasion: Evidence from Russia. American Economic Review, 101(7), 3253-3285.

Fitzpatrick, S., \& Gellately, R. (1996). Introduction to the practices of denunciation in modern European history. The Journal of Modern History, 68(4), 747-767.

Florath, B. (2015). The unofficial collaborators. In D. Münkel (Ed.), State security: $A$ reader on the GDR secret police (pp. 40-51). Bundesbeauftragte für die StasiUnterlagen.

Freedom House. (2015). Freedom in the world 2015: Discarding democracy: Return to the iron fist.

Friedman, H. H., \& Herskovitz, P. J. (1990). The effect of a gift-upon-entry on sales: Reciprocity in a retailing context. American Journal of Business, 5(1), 49-50.

Gang, I. N., \& Stuart, R. C. (1999). Mobility where mobility is illegal: Internal migration and city growth in the Soviet Union. Journal of Population Economics, 12(1), 117-134. 
Garcia-Arenas, J. (2016). The impact of free media on regime change: Evidence from Russia [Working paper]. https://www.amse-aixmarseille.fr/sites/default/files/ events/jmpjavier-1.pdf

Gause, K. E. (2012). Coercion, control, surveillance, and punishment: An examination of the North Korean police state. Committee for Human Rights in North Korea.

Gellately, R. (1988). The Gestapo and German society: Political denunciation in the Gestapo case files. The Journal of Modern History, 60(4), 654-694.

Gieseke, J. (2011). Die Stasi: 1945-1990. Pantheon.

Grdešić, M. (2014). Television and protest in East Germany's revolution, 1989-1990: A mixed-methods analysis. Communist and Post-Communist Studies, 47(1), 93-103.

Greitens, S. C. (2016). Dictators and their secret police: Coercive institutions and state violence. Cambridge University Press.

Grossmann, T. (2015). Fernsehen, Revolution und das Ende der DDR [Television, Revolution and the End of the GDR]. Vallstein Verlag.

Gurr, T. R. (2010). Why men rebel. Paradigm.

Hall, C. M. (2009). An army of spies? The Gestapo spy network 1933 - 45. Journal of Contemporary History, 44(2), 247-265.

Hassan, M. (2017). The strategic shuffle: Ethnic geography, the internal security apparatus, and elections in Kenya. American Journal of Political Science, 61(2), 382-395.

Hempel, M. (1967). Die Wirkung Moralischer Faktoren im Verhalten der Bürger der Deutschen Demokratischen Republik zur Inoffiziellen Zusammenarbeit mit den Organen des Ministeriums für Staatssicherheit. Bundesbeauftragte für die StasiUnterlagen Bundesbeauftragte für die Stasi-Unterlagen, MfS, JHS Nr 21 775, Bd.2 [The Effect of Moral Factors on the Behavior of the Citizens of the German Democratic Republic towards the Unofficial Collaborators with the Organs of the Ministry for State Security. Stasi Records Agency (BStU), MfS, JHS Nr 21 775, Vol. 2].

Kalyvas, S. N. (2006). The logic of violence in civil war. Cambridge University Press.

Kang, J. M. (2014, February 26). Neighborhood watch: Inside North Korea's secret police system. NK News. https://www.nknews.org/2014/02/neighborhoodwatch-inside-north-koreas-secret-service-system/

Katz, D., Caplan, A. L., \& Merz, J. F. (2003). All gifts large and small. American Journal of Bioethics, 3(3), 39-46.

Kern, H. L. (2010). Foreign media and protest diffusion in authoritarian regimes: The case of the 1989 East German revolution. Comparative Political Studies, 44(9), 1179-1205.

Kern, H. L., \& Hainmueller, J. (2009). Opium for the masses: How foreign media can stabilize authoritarian regimes. Political Analysis, 17, 377-399.

Kretchun, N., \& Kim, J. (2012). A quiet opening: North Koreans in a changing media environment. InterMedia.

Kuran, T. (1991). Now out of never: The element of surprise in the East European revolution of 1989. World Politics, 44(1), 7-48. 
Kuschel, F. (2016). Schwarzhörer, Schwarzseher und heimliche Leser: Die DDR und die Westmedien [Secret viewers, secret listeners and secret readers: the GDR and the western media]. Wallstein Verlag.

Lemm, K. M. (2010). Stratified sampling. In N. J. Salkind (Ed.), Encyclopedia of research design (pp. 1452-1454). Sage.

Lohmann, S. (1994). The dynamics of informational cascades: The Monday demonstrations in Leipzig, East Germany, 1989-91. World Politics, 47(01), 42-101.

Mcfaul, M. (2005). Transitions from postcommunism. Journal of Democracy, 16(3), 5-19.

Miner, L. (2015). The unintended consequences of internet diffusion: Evidence from Malaysia. Journal of Public Economics, 132, 66-78.

Mork, L. (2011). Not with me. . .!. Dorrance.

Müller-Enbergs, H. (2001). Inoffizielle Mitarbeiter des Ministeriums für Staatssicherheit. Teil 1: Richtlinien und Durchführungsbestimmungen, Ch. Links Verlag, Berlin [Unofficial collaborators of the Ministry of State Security, Part 1: Guidelines and Implementing Regulations, Berlin: Ch. Links Publishers]

Müller-Enbergs, H. (2008a). Die Inoffiziellen Mitarbeiter [The Unofficial Collaborators]. Bundesbeauftragte für die Stasi-Unterlagen [Stasi Records Agency].

Müller-Enbergs, H. (2008b). Inoffizielle Mitarbeiter des Ministeriums für Staatssicherheit. Richtlinien und Durchführungsbestimmungen, Teil 3: Statistik [Unofficial collaborators of the Ministry of State Security. Part 3: Statistics]. Ch. Links Verlag, Berlin.

Noam, E. M. (1991). Television in Europe. Citeseer.

Peisakhin, L., \& Rozenas, A. (2018). Electoral effects of biased media: Russian television in Ukraine. American Journal of Political Science, 62(3), 535-550.

Persak, K., \& Kamiński, Ł. (2005). A handbook of the communist security apparatus in East Central Europe, 1944-1989. Institute of National Remembrance.

Sassoon, J. (2011). Saddam Hussein's Ba'th party: Inside an authoritarian regime. Cambridge University Press.

Scharpf, A., \& Gläßel, C. (2020). Why underachievers dominate secret police organizations: Evidence from autocratic Argentina. American Journal of Political Science. Advance online publication. https://doi.org/10.1111/ajps.12475

Schlosser, N. J. (2015). Cold war on the airwaves: The radio propaganda war against East Germany. University of Illinois Press.

Schmidt, A. (2010) Hauptabteilung III: Funkaufklärung und Funkabwehr (Handbuch) [Department III: Radio reconnaissance and radio defense (manual)]. Berlin: Stasi Records Agency. http://www.nbn-resolving.org/urn:nbn:de:0292-97839421300667.

Statistisches Amt der DDR [Statistical Office of the GDR]. (1990). Ausstattungsbestand der Haushalte in der Deutschen Demokratischen Republik (DDR) an ausgewählten langlebigen technischen Konsumgütern von 1955 bis 1989 [Household inventory of selected durable technical consumer goods from 1955 to 1989 in the German Democratic Republic (GDR)]. https://de.statista.com/statistik/daten/ studie/249261/umfrage/ausstattung-der-ddr-haushalte-mit-ausgewaehlten-technischen-konsumguetern/ 
Statistisches Jahrbuch der Deutschen Demokratischen Republik [Statistical yearbook of the German Democratic Republic]. (1965). Staatsverl. der DDR [State publisher of the GDR]. http://www.digizeitschriften.de/dms/met/?PPN=PPN514402644

Stegmann, A. (2018). The effects of across-regime interpersonal contact on the support for authoritarian regimes. https://www.carloalberto.org/wp-content/ uploads/2019/01/AS_AcrossRegimeContact.pdf

Stephan, H., \& Wiedemann, E. (1990). Lohnstruktur und Lohndifferenzierung in der DDR . Mitteilungen aus der Arbeitsmarkt- und Berufsforschung, Institut für Arbeitsmarkt- und Berufsforschung der Bundesanstalt für Arbeit (IAB). [Wage structure and wage differentiation in the GDR. Notices from labor market and occupational research, Institute for Labor Market and Occupational Research of the Federal Employment Agency (IAB)]. http://doku.iab.de/mittab/1990/1990_4_ mittab_stephan_wiedemann.pdf

Strömberg, D. (2015). Media and politics. Annual Review of Economics, 7(1), 173-205.

Sullivan, C. M. (2015). Undermining resistance mobilization, repression, and the enforcement of political order. Journal of Conflict Resolution, 60, 1163-1190.

Tarrow, S. (2011). Cambridge studies in comparative politics: Power in movement: Social movements and contentious politics. Cambridge University Press.

Teddlie, C., \& Yu, F. (2007). Mixed methods sampling: A typology with examples. Journal of Mixed Methods Research, 1(1), 77-100.

Thomson, H. (2018). Coercive institutions and repression under authoritarian regimes: Potential insights from archives in Central and Eastern Europe. Comparative Politics Newsletter, 28(1), 79-86.

Thomson, H. (2019, January 14). "Terrifyingly normal” authoritarian bureaucracies: Secret police administration and surveillance in socialist Poland. http://dx.doi. org/10.2139/ssrn.3315626

Witte, E. (1990). Telekommunikation in der DDR und der Bundesrepublik [Telecommunication in the German Democratic Republic and in the Federal Republic of Germany]. R. v. Decker.

\section{Author Biography}

Barbara Maria Piotrowska is a researcher at the Blavatnik School of Government (University of Oxford). Her research focuses on the organization and operation of bureaucracies, and authoritarian survival. 